\title{
Dusting Powder Dosage Form
}

National Cancer Institute

\section{Source}

National Cancer Institute. Dusting Powder Dosage Form. NCI Thesaurus. Code C64883.

A powder intended to be dusted over the outer surface of the body. 